\title{
PEMBINAAN PRANIKAH DALAM PENINGKATAN PEMAHAMAN KEAGAMAAN CALON PENGANTIN DI KUA KECAMATAN SLEMAN
}

\author{
Samsul Alam \\ Program Pasca Sarjana \\ Universitas Muhammadiyah Yogyakarta \\ E-mail: pais_sleman@yahoo.com
}

\begin{abstract}
Abstrak
Tujuan penelitian ini adalah untuk mengetahui pola pembinaan pranikah, seberapa besar peningkatan pemahaman keagamaan bagi calon pengantin serta fctor pendukung dan penghambat pembinaan pranikah. Jenis penelitian ini bersifat kualitatif deskriptif. Tempat penelitian adalah KUA Kecamatan Sleman, dengan subjek penelitian adalah Kepala KUA, Penghulu, Ketatausahaan dan sebanyak 14 pasangan calon pengantin. Teknik pengumpulan data menggunakan angket, wawancara dan observasi. Sedangkan analisis data menggunakan reduksi data, display dan verifikasi data atau kesimpulan. Hasil dari penelitian ini adalah 1) Pola pembinaan yang dilakukan KUA Kecamatan Sleman meliputi model pembinaan, pembimbing pembinaan, materi pembinaan, metode pembinaan dan waktu pembinaan. Secara kesimpulan tingkat pola pembinaan termasuk kategori baik (79,29\%). 2) Tingkat pemahaman keagamaan meliputi pemahaman akad nikah, pemahaman kesehatan reproduksi, pemahaman ibadah dan pemahaman psikologi keluarga. Secara kesimpulan tingkat pemahaman keagamaan termasuk kategori 'Tinggi' (83,04\%). 3) Factor pendukung pembinaan meliputi antusiasme peserta, pembimbing yang kompeten dan metode penyampaian yang sangat sederhana.
\end{abstract}

Kata Kunci : pembinaan calon pengantin, pemahaman keagamaan

\begin{abstract}
The purpose of this study was to determine the pattern of premarital guidance, how much increased religious understanding for the bride and groom supporters and inhibitors of premarital coaching. This type of research is descriptive qualitative. The place of research is KUA Sleman District, with the subjects of the study being the Head of KUA, Penghulu, Administration and as many as 14 pairs of prospective brides. Data collection techniques using questionnaires, interviews and observations. Whereas data analysis uses data reduction, display and data verification or conclusions. The results of this study are 1) The pattern of coaching conducted by the KUA of the Sleman District includes the model of coaching, coaching guidance, coaching material, coaching method and coaching time. In conclusion, the level of coaching pattern is in the good category (79.29\%). 2) The level of religious understanding includes understanding of marriage contract, understanding of reproductive health, understanding of worship and understanding of family psychology. In conclusion, the level of religious understanding is included in the category of 'High' (83.04\%). 3) Supporting factors include the enthusiasm of the participants, competent mentors and very simple delivery methods.
\end{abstract}

Key words: formation of bride and groom, religious understanding

\section{Info Artikel}

Diterima Agustus 2019, disetujui September 2019, diterbitkan Desember 2019 


\section{PENDAHULUAN}

Pernikahan adalah ikatan yang mulia dan diberkahi. Allah SWT mensyari'atkan pernikahan untuk kemaslahatan dan kemanfaatan hamba-hambanya, agar dengan mereka dapat mencapai maksud-maksud yang baik dan tujuan-tujuan yang mulia. Akad nikah adalah perjanjian suci antara seorang pria dan seorang wanita membentuk keluarga bahagia dan kekal. Dalam UU Perkawinan Nomor 1 tahun 1974 Pasal (1) disebutkan bahwa perkawinan adalah ikatan lahir batin antara seorang pria dan seorang wanita sebagai suami istri dengan tujuan membentuk keluarga bahagia yang kekal berdasarkan Ketuhanan Yang Maha Esa. Al Qur`an dan Hadits Nabi memberikan penjelasan bahwa Allah SWT menganjurkan hamba-hambanya untuk menikah bagi mereka yang mampu baik lahir maupun batin karena perkawinan merupakan hal yang penting bagi kehidupan manusia, maka perkawinan yang dilakukan seseorang itu haruslah perkawinan yang sah. Sebagaimana tercantum dalam Pasal 2 UU No. 1 tahun 1974 "Perkawinan adalah sah apabila dilakukan menurut masing-masing agama". Karena menikah dalam UU Perkawinan harus didasarkan pada ajaran agama, maka hal ini selaras dengan prinsip-prinsip Islam bahwa pernikahan adalah bagian dari ajaran Islam. Maka kehidupan seorang muslim tidak sekedar urusan sholat, puasa, haji saja yang menjadi bagian dari Islam, namun juga urusan pernikahan dan keluarga.

Perkawinan menurut Islam adalah merupakan amal ibadah, karena perkawinan merupakan sunnah Rasul, agar nilai keibadahan nikah dapat langgeng maka pasangan suami isteri berkewajiban untuk membentuk rumah tangga yang berkualitas yang masing-masing pasangan suami isteri dapat merawat cinta kasih yang menjadi dasar perkawinan, dapat menyubur kembangkannya dalam kehidupan berumah tangga, sehingga terwujud kehidupan rumah tangga yang serasi, selaras dan seimbang baik kehidupan duniawi maupun ukhrowi.

Untuk mewujudkan kehidupan rumah tangga perlu persiapan yang matang. Persiapan tersebut meliputi persiapan fisik, mental, sumber daya ilmu kerumah tanggaan, ketepatan menjatuhkan pilihan, idealitas usia saat nikah kesiapan menghadapi berbagai problem dan masalah rumah tangga. Dalam perjalanannya, kehidupan keluarga tidak selamanya berjalan sesuai dengan harapan awal yaitu kebahagiaan, kadang-kadang muncul sedikit persoalan yang pada akhirnya ada yang dapat diselesaikan dengan baik, namun ada pula yang tidak dapat diselesaikan dengan baik dan berakhir dengan perceraian. Demikian pula kenyataan banyak keluarga yang berantakan dan belum memperhatikan aturan dasar pembentukan keluarga yang didasarkan ajaran agama sehingga terus meningkatnya angka perceraian juga KDRT (kekerasan dalam rumah tangga). Karena itu salah satu yang penting adalah pembinaan pranikah sebagai salah satu upaya dalam mempersiapkan calon pengantin dalam membentuk rumah tangga yang bahagia. Dalam kenyataan juga banyak ditemukan pasangan pranikah yang belum memahami terhadap seluk beluk tujuan pernikahan dan keluarga sakinah.

Pembinaan bagi calon pengantin merupakan suatu keabsahan pernikahan dari kepedulian pemerintah, hal ini sesuai dengan Peraturan Direktur Jenderal Bimbingan Masyarakat Islam Departemen Agama Nomor: Dj.II/491 Tahun 2009 tentang kursus calon pengantin. Salah satu isi butir peraturan tersebut pasal 1 ayat 2 adalah "kursus calon pengantin yang selanjutnya disebut dengan suscatin adalah pemberian bekal pengetahuan, pemahaman dan ketrampilan dalam waktu singkat kepada catin tentang kehidupan rumah tangga/keluarga. Dalam Peraturan Direktur Dirjen Bimbingan Masyarakat Islam Nomor DJ..II/542 Tahun 2013 Tentang Penyelenggaraan Kursus Pra Nikah Bab III Pasal 3 ayat (2) disebutkan bahwa Kementerian Agama dapat 
menyelenggarakan kursus pra nikah yang pelaksanaannya bekerja sama dengan Badan Penasihatan, Pembinaan, dan Pelestarian Perkawinan (BP4) atau organisasi keagamaan Islam lainnya.

Dibutuhkannya bimbingan pranikah dikarenakan kebutuhan setiap orang akan pengetahuan khususnya tentang pernikahan dan keluarga. Setiap orang yang akan menikah punya rasa penasaran dan ingin mengetahui tentang pernikahan dan cara membentuk keluarga bahagia seperti yang diimpikan setiap orang, maka bimbingan pranikah hadir untuk mengobati rasa penasaran setiap orang tentang pernikahan dan menggambarkan kehidupan rumah tangga yang akan dilalui nanti. Ada kekeliruan sebagian orang tentang cara memperlakukan pasangannya sesudah menikah, menurut sebagian orang itu hanya bagian kecil yang dapat diabaikan tetapi hal kecil itu apabila dilakukan terus-menerus maka akan bersifat fatal untuk kehidupan rumah tangga.

\section{METODE PENELITIAN}

Dalam hal ini peneliti menggunakan jenis penelitian deskriptif kualitatif. Penelitian kualitatif merupakan penelitian yang bermaksud untuk memahami fenomena tentang apa yang dialami oleh subyek penelitian misalnya perilaku, persepsi, motivasi, tindakan, dan lain-lain, secara holistik, dan dengan cara deskripsi dalam bentuk katakata dan bahasa, pada suatu konteks khusus yang alamiah dan dengan memanfaatkan berbagai metode alamiah.

Tempat penelitian atau lokasi penelitian dilaksanakan di Kantor Urusan Agama Kecamatan Sleman Kabupaten Sleman dengan masa pernikahan tahun 2018. Penelitian dilakukan selama 3 bulan yaitu bulan Maret-Mei 2018. Teknik pengumpulan data menggunakan angket, wawancara dan observasi. Sedangkan analisis data menggunakan reduksi data, display dan verifikasi data atau kesimpulan.

\section{HASIL PENELITIAN DAN PEMBAHASAN Pola Pembinaan Pranikah}

Pembinaan merupakan sebuah usaha tindakan dan kegiatan yang dilakukan secara berdaya guna untuk memperoleh hasil lebih baik. Dalam pengembangan program pembinaan, agar pembinaan dapat bermanfaat dan mendatangkan keuntungan diperlukan tahapan atau langkah-langkah yang sistematik. Secara umum ada tiga tahap pada pembinaan yaitu tahap perencanaan pembinaan, tahap pelaksanaan pembinaan dan tahap evaluasi pembinaan. Pola pembinaan pranikah bagi calon pengantin meliputi model pembinaan, pembimbing pembinaan, metode pembinaan, materi pembinaan dan waktu pelaksanaan pembinaan.

Berdasarkan penjelasan tentang pola pembinaan pranikah calon pengantin dapat disimpulkan bahwa pola pembinaan pranikah termasuk kategori Baik $(77,86 \%)$. Hal ini dapat diperhatikan pada tabel berikut: 
Tabel 1.

Pola Pembinaan Pranikah

\begin{tabular}{|c|l|c|c|c|c|}
\hline No & \multicolumn{1}{|c|}{ Kategori } & Jumlah Skor & Persentase (\%) & Rata-rata & Kategori \\
\cline { 1 - 4 } 1 & Model & 47 & 83.93 & & \\
\cline { 1 - 4 } 2 & Pembimbing & 50 & 89.29 & \multirow{2}{*}{79.29} & \multirow{2}{*}{ Baik } \\
\cline { 1 - 4 } 3 & Materi & 46 & 82.14 & \\
\cline { 1 - 4 } 4 & Metode & 48 & 85.71 & & \\
\hline
\end{tabular}

\section{Tingkat Pemahaman Keagamaan Calon Pengantin}

Pemahaman adalah kemampuan seseorang dalam mengartikan, menafsirkan, menterjemahkan atau menyatakan sesuatu dengan caranya sendiri tentang pengetahuan yang pernah diterima. Sedangkan menurut Anas Sudjiono pemahaman adalah kemampuan seseorang untuk mengerti sesuatu setelah sesuatu itu diketahui dan diingat. Dengan kata lain, memahami adalah mengetahui tentang sesuatu dan dapat melihatnya dari berbagai segi. Pemahaman merupakan jenjang kemampuan berpikir yang setingkat lebih tinggi dari ingatan dan hafalan. Berdasarkan dari pengertian di atas, dapat disimpulkan bahwa pemahaman adalah sebuah kemampuan yang dimiliki oleh seseorang dalam mengartikan atau menerjemahkan sesuatu dengan caranya sendiri. Mereka dapat mengartikan apa yang mereka peroleh dari pengetahuan yang mereka terima. Jadi, sebuah pemahaman itu memiliki tingkat kemampuan yang lebih tinggi dibandingkan dengan hafalan atau ingatan.

Di usia dewasa biasanya seseorang sudah mamiliki sifat kepribadian yang stabil. Stabilisasi sifat-sifat kepribadian ini antara lain terlihat dari cara bertindak dan bertingkah laku yang agak bersifat tetap (tidak mudah berubah-ubah) dan selalu berulang kembali atau konsisten. Kemantapan jiwa orang dewasa ini setidaknya memberikan gambaran tentang bagaimana sikap keberagamaan pada orang dewasa. Mereka sudah mempunyai tanggung jawab terhadap system nilai yang dipilihnya, baik system nilai yang bersumber dari ajaran agama maupun yang bersumber dari normanorma lain dalam kehidupan. Pemilihan nilai-nilai tersebut telah didasarkan atas pertimbangan pemikiran yang matang. Berdasarkan hal ini, maka sikap keberagamaan seorang di usia dewasa sulit untuk di ubah. Jika pun terjadi perubahan mungkin proses itu terjadi setelah didasarkan atas pertimbangan yang matang.

Berdasarkan penjelasan di atas, dapat disimpulkan bahwa peningkatan pemahaman keagamaan calon pengantin adalah tinggi (83,04\%). Hal ini seperti digambarkan dalam tabel berikut: 
Tabel 2.

Pemahaman Keagamaan Calon Pengantin

\begin{tabular}{|c|c|c|c|c|c|}
\hline No & Indikator & Skor & Persentase & Rata-rata & Kategori \\
\hline 1 & Tata Cara Akad & 51 & 91.07 & \multirow{10}{*}{83.04} & \multirow{10}{*}{ Tinggi } \\
\hline 2 & Kesehatan Reproduksi & 48 & 85.71 & & \\
\hline 3 & Sholat Wajib & 48 & 85.71 & & \\
\hline 4 & Sholat Jama'ah & 45 & 80.36 & & \\
\hline 5 & Membaca al-Qur'an & 44 & 78.57 & & \\
\hline 6 & Banyak Berdoa & 51 & 91.07 & & \\
\hline 7 & Banyak Berusaha & 52 & 92.86 & & \\
\hline 8 & Giat Bekerja & 50 & 89.29 & & \\
\hline 9 & Tawakal kpd Allah & 45 & 80.36 & & \\
\hline 10 & Bersyukur & 31 & 55.36 & & \\
\hline
\end{tabular}

\section{Factor Pendukung dan Penghambat Pembinaan Pranikah}

Pelaksanaan bimbingan pranikah bagi calon pengantin di KUA Kecamatan Sleman sudah cukup efektif. Sebuah program tidak terlepas dari factor pendukung dan faktor penghambat. Begitu pula dengan program bimbingan pranikah di KUA Kecamatan Sleman. Untuk factor pendukung pembinaan pranikah meliputi antusiasme peserta, pembimbing yang kompeten dan metode penyampaian yang sangat sederhana. Sedangkan factor penghambat meliputi sarana dan prasana yang belum memadai, materi bimbingan yang kurang lengkap dan waktu bimbingan yang sangat singkat.

\section{SIMPULAN DAN REKOMENDASI}

Dari hasil kajian yang telah dilakukan oleh peneliti, maka penelitian ini menyimpulkan sebagai berikut:

1. Pola pembinaan yang dilakukan KUA Kecamatan Sleman meliputi model pembinaan, pembimbing pembinaan, materi pembinaan, metode pembinaan dan waktu pembinaan. Secara kesimpulan tingkat pola pembinaan termasuk kategori baik $(79,29 \%)$.

2. Tingkat pemahaman keagamaan meliputi pemahaman akad nikah, pemahaman kesehatan reproduksi, pemahaman ibadah dan pemahaman psikologi keluarga. Secara kesimpulan tingkat pemahaman keagamaan termasuk kategori 'Tinggi' $(83,04 \%)$.

3. Factor pendukung pembinaan meliputi antusiasme peserta, pembimbing yang kompeten dan metode penyampaian yang sangat sederhana. Sedangkan factor penghambat meliputi sarana dan prasana yang belum memadai, materi bimbingan yang kurang lengkap dan waktu bimbingan yang sangat singkat. 


\section{DAFTAR PUSTAKA}

Anas Sudjiono, Pengantar Evaluasi Pendidikan, Jakarta: PT Grafindo Persada, 1996

Bagian Proyek Pembinaan Keluarga Sakinah Kanwil Departemen Agama Prop DIY, Pendidikan Pra Nikah dan Pembinaan Kehidupan Beragama Dalam Keluarga

Departemen Pendidikan Nasional, Kamus Besar Bahasa Indonesia, Jakarta: Balai Pustaka, 2005

Lexy J. Moleong, Metodologi Penelitian Kualitatif, Bandung: Remaja Rosda karya, 2001

Moh. Idris Ramulyo, Hukum Perkawinan Islam, Jakarta: Bumi Aksara, 1979

Nur Ahid, Pendidikan Keluarga dalam Perspektif Islam Yogyakarta: Pustaka Pelajar, 2000

Pawito, Penelitian Komunikasi Kualitatif Cetakan Pertama. Yogyakarta: LkiS, 2007

Singgih D. Gunarso, Dasar dan Teori Perkembangan Anak, Jakarta: BPK Gunung Mulia, 1990

Sugiyono, Memahami Penelitian Kualitatif, Bandung: Alfa Beta, 2005

Suharsimi Arikunto, Prosedur Penelitian Suatu Pendekatan Praktik, Jakarta: Rineka Cipta, 1995 